\title{
Estetyka granic
}

Najciekawsze są obszary graniczne. Tam, na styku różnych światów, obcych kultur, odrębnych państw, innych bytów i barw, odmiennych poglądów i przekonań tworzą się nowe, zaskakujące jakości.

Różnica wytwarza wartości sprzeczne: buduje dystans i zarazem określa przyciąganie, definiuje na chwilę status bytu tylko po to, by już za moment rozsypać misternie tworzoną całość, ujawniając jej fragmentaryczność i niestabilność. Rzeczy bytują w ruchu, świat naszych wyobrażeń zastyga $\mathrm{w}$ jednej formule $\mathrm{w}$ oczekiwaniu na zmienne światło, które wydobędzie $\mathrm{z}$ nich nowe odcienie, przedefiniuje ich status, uczyni jasnym to, co było w cieniu, odsunie w niebyt to, co trwało jako jednoznaczne, zachwyci się tym, co uznane zostało za niepewne i zmienne.

Granica zadaje pytania, stwarza problemy, stawia na konflikt i zawłaszczanie. Granica daje odpowiedzi, ujawnia odmienność jako odbicie lustrzane, pokazuje możliwość przekształcania i redefinicji zastanego. Graniczność nie zatrzymuje, ale uobecnia przemianę, prowokuje działanie, pociąga za sobą nieskończoną liczbę powtórzeń, przedrzeźnień, przekształceń, stwarza szansę powstania nowych obrazów.

Przygraniczność wytwarza estetykę transgresji. Przekraczanie związane z dekonstrukcją powołało przestrzenie - mówiąc językiem Jacques’a Derridy - rozsunięć, nacięć, zerwań, zranień. Przestrzenie dekonstrukcji nie stały się jednak nigdy polami destrukcji. Nawet palone płótna obrazu, dając popiół, wskazywały na nową jakość materii.

Świat ludzki zatrzymuje się na styku roślin i zwierząt (mówiące sekwoje), żywa istota łączy się z martwą formą (antropomorficzny manekin), szaleństwo rozdziera jedność podmiotu (ja i nie-ja), gatunek wypowiedzi wyznacza charakter tożsamości (portret epistolarny). Graniczność buduje nową estetykę, która nie tylko powołuje byty niejednorodne, stwarza wartości antybinarne, ale ujawnia dramatyzm nowych kategorii rodzących się w sztuce nacięć, z pozoru już tylko, gładkich powierzchni. Roślina staje się partnerem człowieka $\mathrm{w}$ dialogu na temat cywilizacji i natury, wzrusza zrozumieniem sensu swojej zagłady. Manekin przeraża martwotą dlatego, że udaje życie, wyrażając je poprzez śmiertelne znieruchomienie. Człowiek szuka swej tożsamości w sztuce i szaleństwie, które pokazują mu własny obraz poprzez dystans wobec tego, o czym sądził, że jest dalekie i obce.

Estetyka granic przyciąga i odpycha równocześnie. Jest grą bycia „w” i trwania „na zewnątrz”. Ta przestrzeń transwersalna, przekształcająca

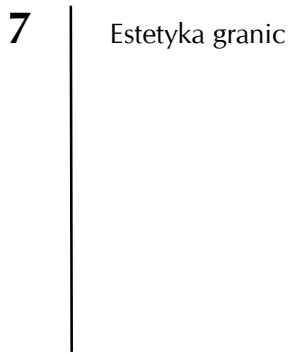


obszary po obu stronach wyznaczonej stycznością linii, pozostaje pod wpływem dwóch sprzecznych sił, które z jednej strony wyostrzają ją, uwyraźniają, wzmacniają i różnicują jej charakter, z drugiej zaś rozmazują i zacierają, sprawiając, że możemy na skraju dwóch - jak je nazwał Tadeusz Różewicz - „niekolorów”, czyli bieli i czerni, zobaczyć jeszcze szarość.

Anna Krajewska 